\title{
A Study of Serum Ferritin Level in Female Patient with Alopecia
}

\author{
Manish Pradhan, ${ }^{1}$ Dipa Rai, ${ }^{1}$ Sagar Paudel ${ }^{1}$ \\ ${ }^{1}$ Department of Dermatology, Nobel Medical College, Biratnagar Nepal.
}

\begin{abstract}
Introduction: Total body iron store is an integral factor in the development of hair follicle. Numerous studies have been done seeking for the relationship between body iron store and various forms of chronic diffuse hair loss, with relatively contradictory findings in various reports in these studies. The main objective of this study is to find out if there is any association between total body iron store and various types of chronic diffuse hair loss in females in reproductive age. Materials and Methods: This is a hospital based case control study conducted in Nobel Medical College and Teaching Hospital, Biratnagar, Nepal. Sixty female patients of age group 15-50 years with chronic diffuse hair loss with equal number of age- and sexmatched controls were studied. Both of the study groups were evaluated for various parameters of iron status. Results: The mean value of serum ferritin in cases was significantly lower as compared to controls $(\mathrm{p}=0.018)$. Patients with alopecia areata $(\mathrm{p}=0.008)$ and androgenetic alopecia $(\mathrm{p}=0.021)$ had significantly lower serum ferritin, whereas there was no statistically significant difference in telogen effluvium and controls $(\mathrm{p}=0.857)$. The mean value of hemoglobin, hematocrit and mean corpuscular hemoglobin was found to be significantly lower in alopecia areata and androgenetic alopecia. However, there was no statistically significant difference in RBC indices of patients of telogen effluvium and controls. Conclusion: Diffuse chronic hair loss shows definite association with serum ferritin and various RBC indices in female of reproductive age group. Alopecia areata and androgenetic alopecia show major association with total body iron stores.
\end{abstract}

Keywords: alopecia areata; androgenetic alopecia; serum ferritin; telogen effluvium.

\section{INTRODUCTION}

Hair, having no any specific physiological importance in human, has significant social, psychological and cosmetic importance. Chronic diffuse hair loss, in women is associated with great distress.

A human scalp on average has about 100,000 hairs. Each hair grows for about 1000 days and 100 telogen hair shed. ${ }^{1}$ Hair passes through three stages of growth and shedding. The hair follicles are not synchronized in growth. The stages include anagen $(86 \%)$, catagen $(1 \%)$ and telogen $(13 \%)^{2}$

Alopecia by definition is the loss of hair from a normally hairy area. ${ }^{3}$ Diffuse hair loss usually occurs without inflammation or scarring. The loss affects hairs throughout the scalp in a more or less uniform pattern. ${ }^{1}$ Like other organs hair also needs adequate nutrition as evidenced by its affect in various nutritional diseases. ${ }^{4,5}$ Protein energy malnutrition in particular causes significant hair changes. ${ }^{4,5}$ Besides this, various micronutrients have also been implicated as etiological factors of hair loss. ${ }^{6,7}$

Iron deficiency is the most common nutritional deficiency disorder of the world. Hb, Hct, MCV, $\mathrm{MCHC}, \mathrm{MCH}$ and serum ferritin correlate with the amount of total body iron store. Ever since one of the earliest study performed by Hard in 1963, comparing the relationship between diffuse scalp hair loss and iron deficiency as measured by serum iron, various contradictory studies have been published. ${ }^{6}$ A case control study by Rushton et al. showed that almost three-quarters of 50 premenopausal women with diffuse scalp alopecia had serum ferritin level less than $40 \mathrm{mcg} / \mathrm{L}{ }^{7}$ Therefore this study was done to evaluated the relationship between chronic diffuse hair loss and total body iron status.

\section{MATERIALS AND METHODS}

The Institutional Review Committee approved the study. The study was conducted from 1st march

Correspondence: Dr. Manish Pradhan, Department of Dermatology and Venerology, Nobel Medical College Teaching Hospital, Biratnagar, Nepal. Email. drmanishpradhan1@gmail.com. DOI: $10.3126 /$ jcmsn.v14i2.20217. Article received: 2018-06-11. Article accepted: 2018-06-26. 
2017 to 28 February 2018. Written consent was taken from all the study subjects before their inclusion in the study. The study comprised of 120 female patient of reproductive age group (15-50 years) presenting to the dermatology department of Nobel Medical College and Teaching Hospital, Biratnagar, of which 60 were case and 60 controls. The diagnosis of various types of alopecia was made on the basis of history and clinical examination. Androgenetic alopecia, telogen effluvium and alopecia areata were included in the study. Inclusion criteria for cases: all the consenting female patients of age group 15-50 years with chronic hair loss. Exclusion criteria for cases: Participants on iron, folic acid, vitamin B12, pregnancy in the preceding one year, undergoing major surgery, endocrine abnormalities, on medication for systemic disorders and acute inflammatory condition. Inclusion criteria for controls: the control group comprised of age and sex matched patients presenting to the dermatology department for some other dermatological abnormality not directly related to alopecia of iron deficiency. Exclusion criteria for controls: Participants on iron, folic acid, vitamin B12, pregnancy in the preceding one year, undergoing major surgery, endocrine abnormalities, on medication for systemic disorders and acute inflammatory condition. The baseline investigations used to measure the total body iron store included serum ferritin, blood hemoglobin $(\mathrm{Hb})$, hematocrit (Hct), mean corpuscular volume (MCV), mean corpuscular hemoglobin concentration (MCHC) and mean corpuscular hemoglobin $(\mathrm{MCH})$.

The parameters for the study of total body iron status was performed on venous blood using Chemico Lumino Immuno Assay (CLIA) for serum ferritin and Fully Automated Cell Counter for $(\mathrm{Hb}$, Hct, MCV, MCHC and $\mathrm{MCH}$ ). The normal values for serum ferritin was taken as $20-200 \mathrm{ng} / \mathrm{mL}$ and $\mathrm{Hb}$, Hct, MCV, MCHC, MCH were12-16gm/dl, 36$48 \%, 80-96 \mathrm{fL}, 33-36 \mathrm{gm} / \mathrm{dL}, 30-33 \mathrm{pg}$ respectively. The analysis of the data was performed by using SPSS version 22. The statistical analysis of the data was done using mean \pm standard deviation, and independent $\mathrm{t}$-test. The test was referenced for $\mathrm{p}$ values and $p$ value of less than 0.05 was taken to be significant.

\section{RESULTS}

The age range of cases and controls in our study was 15-50 years with mean age of $33.93 \pm 11.02$ years in cases and $34.97 \pm 10.42$ years in controls. Out of 60 female patients of alopecia, 23 were suffering from alopecia areata, 18 from androgenetic alopecia and 19 had telogen effluvium.

The mean value of hemoglobin $(9.38 \pm 1.66 \mathrm{~g} / \mathrm{dl}$ c.f. $10.48 \pm 1.61 \mathrm{~g} / \mathrm{dl} ; \mathrm{p}=0.001)$, hematocrit $(29.47$ $\pm 5.48 \%$ c.f. $32.06 \pm 6.16 \% ; \mathrm{p}=0.016)$ and mean corpuscular hemoglobin $(27.07 \pm 3.54$ pg c.f.29.13 $\pm 3.87 \mathrm{pg} ; \mathrm{p}=0.003$ ) was found to be significantly lower than the control group in our study. But Mean corpuscular volume $(81.23 \pm 8.47 \mathrm{fl})$ and Mean corpuscular hemoglobin concentration (30.85 \pm $1.82 \mathrm{~g} / \mathrm{dl}$ ) were not significantly lower than that of controls as shown in Table 1.

\begin{tabular}{|llll|}
\hline \multicolumn{4}{|l|}{$\begin{array}{l}\text { Table 1. Comparison of Red Blood Cell indices } \\
\text { between Cases and Controls. }\end{array}$} \\
\hline RBC indices & $\begin{array}{l}\text { Cases } \\
\text { Mean } \pm \text { S.D. }\end{array}$ & $\begin{array}{l}\text { Controls } \\
\text { Mean } \pm \text { S.D. }\end{array}$ & P \\
& value \\
$\mathrm{Hb}(\mathrm{g} / \mathrm{dl})$ & $9.38 \pm 1.66$ & $10.48 \pm 1.61$ & $0.001^{*}$ \\
$\mathrm{Hct}(\%)$ & $29.47 \pm 5.48$ & $32.06 \pm 6.16$ & $0.016^{*}$ \\
$\mathrm{MCV}(\mathrm{fl})$ & $81.23 \pm 8.47$ & $84.11 \pm 9.21$ & 0.077 \\
$\mathrm{MCH}(\mathrm{pg})$ & $27.07 \pm 3.54$ & $29.13 \pm 3.87$ & $0.003^{*}$ \\
$\begin{array}{l}\text { MCHC (g/ } \\
\text { dl) }\end{array}$ & $30.85 \pm 1.82$ & $31.52 \pm 2.38$ & 0.085 \\
\hline
\end{tabular}

*Statistically significant at $\mathrm{p}<0.05$

The mean serum ferritin in cases $(19.68 \pm 8.70 \mathrm{ng} /$ $\mathrm{ml}$ ) was found to be significantly lower than controls $(23.14 \pm 6.99 \mathrm{ng} / \mathrm{ml})[\mathrm{p}=0.018]$ as shown in Table 2. On further analysis of subgroups of alopecia, the mean serum ferritin in alopecia areata $(18.12 \pm 8.70 \mathrm{ng} / \mathrm{ml})$ and androgenetic alopecia $(18.39 \pm 9.14 \mathrm{ng} / \mathrm{ml})$ was significantly lower than that in controls ( $\mathrm{p}=0.008$ and $\mathrm{p}=0.021$ respectively). Although the mean serum ferritin of patients with telogen effluvium $(22.79 \pm 7.85 \mathrm{ng} / \mathrm{dl})$ was lower than that of controls $(23.14 \pm 6.99 \mathrm{ng} / \mathrm{ml})$, but there was not statistically significant difference $(\mathrm{p}=0.857)$ as shown in Table 2.

\begin{tabular}{|c|c|c|c|}
\hline Study group & Number & $\begin{array}{l}\text { Mean } \pm \text { S.D. } \\
(\mathrm{ng} / \mathrm{ml})\end{array}$ & $\begin{array}{l}\mathbf{p} \\
\text { value }\end{array}$ \\
\hline Alopecia areata & 23 & $18.12 \pm 8.70$ & $0.008 *$ \\
\hline $\begin{array}{l}\text { Androgenetic } \\
\text { alopecia }\end{array}$ & 18 & $18.39 \pm 9.14$ & $0.021 *$ \\
\hline $\begin{array}{l}\text { Telogen efflu- } \\
\text { vium }\end{array}$ & 19 & $22.79 \pm 7.85$ & 0.857 \\
\hline Total cases & 60 & $19.68 \pm 8.70$ & $0.018 *$ \\
\hline Controls & 60 & $23.14 \pm 6.99$ & \\
\hline
\end{tabular}

*Statistically significant at $\mathrm{p}<0.05$

We further analyzed the data of various RBC indices on different subgroups of alopecia. The mean value of hemoglobin, hematocrit and mean 
Pradhan et al. A study of serum ferritin level in female patient with alopecia.

corpuscular hemoglobin was found to be significantly lower in alopecia areata and androgenetic alopecia, whereas mean corpuscular volume and mean corpuscular hemoglobin concentration was not significantly different from that of controls as shown in Table 3. also found mean serum ferritin level to be significantly lower in cases than in control. ${ }^{8,9}$ our study contrast with study done by Oslen et. al. and Sinclair who shows there is no association between alopecia and serum ferritin. ${ }^{10,11}$

\begin{tabular}{|llllll|}
\hline \multicolumn{2}{|l}{ Table 3: Comparison of various RBC indices in cases (subgroups) and controls. } \\
\hline RBC Indices & $\begin{array}{l}\text { Controls } \\
\text { Mean } \pm \text { S.D. }\end{array}$ & Alopecia areata & & Androgenetic alopecia \\
& & Mean \pm S.D. & P value & Mean \pm S.D. & P value \\
$\mathrm{Hb}(\mathrm{g} / \mathrm{dl})$ & $10.48 \pm 1.61$ & $9.20 \pm 1.68$ & $0.002^{*}$ & $8.95 \pm 1.83$ & $0.001^{*}$ \\
$\mathrm{Hct}(\%)$ & $32.06 \pm 6.16$ & $28.45 \pm 5.82$ & $0.017 *$ & $28.48 \pm 5.86$ & $0.032^{*}$ \\
$\mathrm{MCV}(\mathrm{fl})$ & $84.11 \pm 9.21$ & $80.87 \pm 7.66$ & 0.137 & $81.12 \pm 11.98$ & 0.264 \\
$\mathrm{MCH}(\mathrm{pg})$ & $29.13 \pm 3.87$ & $27.13 \pm 3.12$ & $0.030^{*}$ & $26.42 \pm 4.83$ & $0.017^{*}$ \\
$\mathrm{MCHC}(\mathrm{g} / \mathrm{dl})$ & $31.52 \pm 2.38$ & $31.27 \pm 2.02$ & 0.657 & $30.69 \pm 1.78$ & 0.175 \\
\hline
\end{tabular}

*Statistically significant at $\mathrm{p}<0.05$

However, there was no statistically significant difference in $\mathrm{RBC}$ indices $(\mathrm{Hb}, \mathrm{Hct}, \mathrm{MCV}, \mathrm{MCH}$, $\mathrm{MCHC}$ ) of patients of telogen effluvium and that of controls as shown in Table 4.

\begin{tabular}{|llll|}
\hline \multicolumn{3}{|l|}{ Table 4. Comparison of mean serum ferritin of } \\
various subgroups of alopecia and controls.
\end{tabular}

*Statistically significant at $\mathrm{p}<0.05$

\section{DISCUSSION}

Our result shows that alopecia areata was most common type of non scaring alopecia, followed by telogen effluvium and then androgenetic alopecia.

Diverse result has been observed regarding the relation between non scaring alopecia and serum ferritin level and RBC indices. So, the present case control study was done to see if there is any correlation between serum ferritin level and non scaring alopecia.

In our study we found mean serum ferritin level was significantly lower in cases than in control. Regarding serum ferritin level our study is in correlation with Kantor et al. and Chitsi et al. who
On further analysis we found that serum ferritin level was significantly lower in patient with alopecia areata and chronic androgenic alopecia ( $\mathrm{p}$ $<0.05)$ but in patient with telogen effluvium it was lower but not significantly lower $(\mathrm{p}>0.05)$.

Kantor et al. and Chitsi et al. also found serum ferritin level was significantly lower in patient with alopecia areata and androgenetic alopecia but it was lower but not significantly lower in patients with telogen effluvium like our result. ${ }^{8,9}$

White et al. in Denmark concluded that female patients with alopecia areata had an increased incidence of iron deficiency compared with the general population. ${ }^{12}$ They suggested serum ferritin measurement should be a necessary part of the work up in patients with alopecia areata. Esfandiarpour I also found that serum ferritin in patient with alopecia areata to be lower but it was not significantly lower. ${ }^{13}$ Ferritin has been reported to exhibit different immunological activities such as suppression of antibody production by lymphocytes and suppression of delayed type hypersensitivity. The ferritin levels are increased in inflammation, infections, malignancies and autoimmune diseases. ${ }^{14}$ Since alopecia areata is an autoimmune disease, there must be changes in serum ferritin and iron levels. ${ }^{15}$

Park SY et al. found it to significantly lower in patients with androgenetic alopecia. ${ }^{16}$ But in contrast to our result Moeinvazir $M$ et al. found serum ferritin to be significantly lower in patients with telogen effluvium. ${ }^{17}$ In large population based 
study done by Deloche $\mathrm{C}$ et al. in 5110 women where they found low iron store represents a risk factor for hair loss $\mathrm{n}$ non menopausal women. ${ }^{18}$ The cut off value was $<40 \mathrm{microg} / \mathrm{L}$. Oslen et al. took two cut off value for serum ferritin level 15 microg/L and 40 microg/L and in both the value they found that low serum ferritin was not seen in patient with hair loss. ${ }^{10}$

How much value of serum ferritin to be taken as lower limit is the matter of debate for modern trichologist. Rushton and Ramsay found that women with androgenetic alopecia responded best to treatment with antiandrogen cyproterone acetate and thinly estradiol when their serum ferritin level was above $40 \mathrm{ng} / \mathrm{ml}^{19}$

Apart from serum ferritin there has also been result of other micronutrients that is associated with hair loss in women. Rasheed et al. found serum ferritin and vitamin D significantly lower in patients with androgenic alopecia and telogen effluvium. ${ }^{20}$ Jin et al. found that no significant difference in level of serum ferritin and copper level in patients with alopecia areata but found that for serum zinc and selenium it was significantly lower. ${ }^{21}$

In our study we also found that RBC indices like the mean value of hemoglobin, hematocrit and mean corpuscular hemoglobin were found to be significantly lower in patients than the control group in our study. But Mean corpuscular volume and Mean corpuscular hemoglobin concentration were not significantly lower than that of controls. Like our result Muzami et al. also found hemoglobin, hematocrit and mean corpuscular hemoglobin to be significantly lower in patients. ${ }^{9}$

\section{REFERENCES}

1. Jadavji T, Humphreys RP, Prober CG: Brain abscesses in infants and children. Pediatr Infect Dis 1985;4:394-98.

2. Roberts J, Bartlett AH, Giannoni CM, Valdez TA: Airway foreign bodies and brain abscesses: Report of two cases and review of the literature. Int J Pediatr Otorhinolaryngol 2008; 72:265-69.

3. Habif T.P. (2016). Clinical dermatology: A color guide to diagnosis and therapy. Sixth edition. Handover, NH, USA: Elsevier; 926, 930.

4. Barman JM, Astore I, Pecaro V. The normal trichogram of adult. J Invest Dermatol 1965; 44:233-6.

5. Van Neste DJ, Rushton DH. Hair problems in women. ClinDermatol1997; 15:113-25.

6. Bradfield RB, Cordario A, Graham GG. Hair
Serum ferritin level, Mean hemoglobin level and $\mathrm{RBC}$ indices were found to be in lower side in both cases and control. This may be due to high prevalence of anemia in the community of the study population of country like Nepal. One-third Nepalese women $(35.0 \%)$ are suffering from anemia; $29.0 \%$ fall under mildly anemic. ${ }^{22} \mathrm{Nepal}$ holds the evidences of alarming rate of anemia among the women of reproductive age. ${ }^{23}$

\section{CONCLUSION}

Diffuse chronic hair loss shows definite association with serum ferritin and various RBC indices in female of reproductive age group. Alopecia areata and androgenetic alopecia show major association with total body iron stores. Apart from serum ferritin other micronutrients like vitamin $\mathrm{D}$, copper, zinc and selenium may also be associated with hair loss in premenopausal female. So we suggest that iron stores, $\mathrm{RBC}$ indices and micronutrient profile has to be evaluated for better management of alopecia in female. We recommend the female patient presenting with hair loss has to be evaluated for RBC indices and serum ferritin level.

\section{Limitation of study}

The study would be more informative if other micronutrients like zinc, selenium, cooper and vitamin $\mathrm{D}$ were also evaluated as their level also correlate with hair loss in females.

\section{ACKNOWLEDGEMENT}

We are very grateful to Dr. Niraj Nepal, Department of pathology, Nobel Medical College and all the laboratory staffs who help to collect data for our study.

root adaptation to marasmus. Lancet 1969; ii: 1395-6.

7. Bradfield RB, Bailey MA. Hair root response to under nutrition. In: Montagna W, Dobson RL, eds. Hair Growth. Oxford: Pergamon; 1969. P. 109-19.

8. Hard S. Non-anemic iron deficiency as an etiological factor in diffuse loss of hair of the scalp in women. ActaDermVenereol1963; 43:562-9.

9. Rushton DH. Nutritional factors and hair loss. Clin and Exp Dermatol2002; 27:396-404.

10. Kantor J, Kessler LJ, Brooks DG, Costarelis G. Decreased serum ferritin is associated with alopecia in women. J Invest Dermatol. 2003 Nov; 121(5): 985-8.

11. Muzamil A Chisti, Qazi Masood, Iffat H shah, Dilshand Khan, Imran Majid, Seema Qayoom, 
Pradhan et al. A study of serum ferritin level in female patient with alopecia.

Samreen Shah. J Pakistan Association of Dermatologist. 2012; 22:4-11.

12. Oslen EA, Reed KB, Cacchio PB, Caudil L. Iron deficiency in female pattern hair loss, chronic telogen effluvium, and control groups. J Am AcadDermatol. 2010 Dec; 63:991-9.

13. Sinclair R. There is no clear association between low serum ferritin and chronic diffuse telogen hair loss. Br J Dermatol. 2002 Nov; 147(5): 982-4.

14. White MA, currie J, Williams MP. A study of the tissue iron status of patients with alopecia areata. $\mathrm{Br} \mathrm{J}$ Dermatol 1994; 130: 261-3.

15. Esfandiarpour I, Farajzadeh S, Abbaszadeh M. Evaluation of serum iron and ferritin levels in alopecia areata. Dermatol online J. 2008 Mar 15; 14 (3) 21.

16. Zandman-Goddard G, Shoenfeld Y. Ferritin in autoimmune disease. Autoimmun Rev 2007; 6:45763.

17. Aejaz Ali Wani, Nighat Jan. Serum iron and ferritin levels in alopecia areata Iran J Dermatol 2011; 14: 92 $-94$

18. Park SY, Na SY, Kim JH, Lee JH. Iron plays a certain role in patterned hair loss. J Korean Med Sci. 2013 Jun; 28(6): 934-8.

19. Moeinvaziri M, Mansoori P, Holakooee K, SafaeeNaraghi, Abbasi A. Iron status in diffuse telogen hair loss among women. ActaDermatovenerol Croat. 2009; 17(4):279-84.
20. Deloche C, Bastien P, Chadoutaud S, Galan P, Bertrais S, Hercberg S, de Lacharriere O. Low iron stores: a risk factor for excessive hair loss in nonmenopausal women. Eur J Dermatol. 2007 Nov-Dec (6): 507-12.

21. Rushton HD, Ramsay ID. The importance of adequate serum ferritin levels during oral cyproterone acetate and ethinyloestradiol treatment of diffuse androgen dependent alopecia in women. ClinEndocrinol 1992; 36:421-7.

22. Rasheed H, Mahgoub D, Hegazy R, El-Komy M, Abdel hay R, Hamid MA, Hamdy E. Serum ferritin and vitamin $\mathrm{d}$ in female hair loss: do they play a role? Skin Pharmacol Physiol. 2013; 26(2): 101-7.

23. Jin W, Zheng H, Shan B, Wu Y. Changes of serum trace elements level in patients with alopecia areata: A metaanalysis. J Dermatol.2017 May; 44(5): 558591.

24. Ministry of health and Population (MOPH) [Nepal], New ERA, ICF International Inc: Nepal Demographic and Health Survey 2011. Kathmandu, Nepal: Ministry of Health and Population, New ERA, and ICF International, Calverton, Maryland; 2012.

25. DOHS. Annual Report 2012/2013. Kathmandu: Department of Health Services, Ministry of Health and Population, Government of Nepal; 2014.

Citation: Pradhan M, Rai D, Paudel S. A Study of Serum Ferritin Level in Patient with Alopecia. JCMS Nepal. 2018;14(2):115-9. 